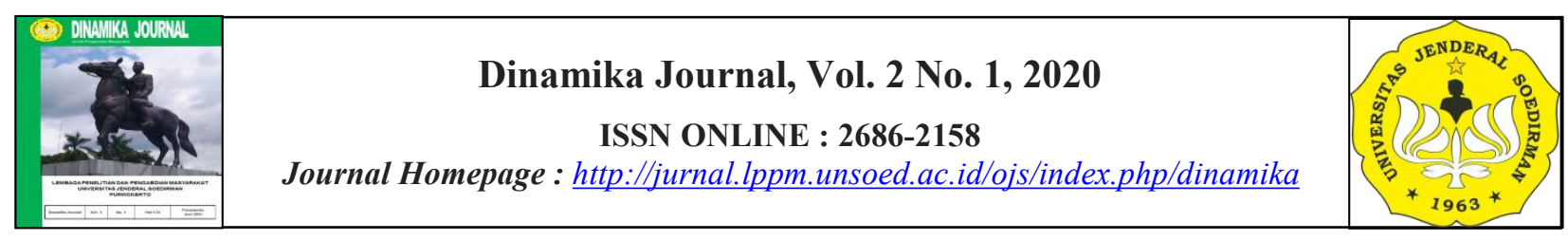

\title{
PENINGKATAN PRODUKSI IKAN LELE DUMBO DENGAN PEMBERIAN SUPLEMEN VITAMIN C
}

\author{
Nuning Setyaningrum ${ }^{*}$, Sugiharto ${ }^{1}$, Sri Sukmaningrum ${ }^{1}$ \\ ${ }^{1}$ Fakultas Biologi, Universitas Jenderal Soedirman, Indonesia \\ *Corresponding author: nuning.setyaningrum67@gmail.com
}

Received 27 September 2019; Accepted 22 January 2020; Available online 16 February 2020

\begin{abstract}
Abstrak
Desa Candiwulan salah satu desa di Kabupaten Banjarnegara yang memiliki potensi dalam bidang perikanan yang didukung dengan cukup tersedia air meskipun pada musim kemarau. Salah satu jenis ikan yang dibudidayakan adalah ikan lele dumbo. Kendala yang sering dihadapi dalam budidaya ikan lele dumbo adalah tahapan pendederan yaitu tahapan awal pemeliharaan benih setelah persediaan kuning telur habis. Tahapan benih dalam budidaya ikan lele dumbo merupakan tahapan kritis sehingga kelangsungan hidupnya rendah. Perlu dilakukan dengan peningkatan kekebalan tubuh dengan penambahan suplemen vitamin $C$ dalam pakan. Tujuan melakukan kegiatan pengabdian kepada masyarakat adalah mendidik masyarakat desa Candiwulan menjadi paham dengan manajemen pemberian suplemen vitamin $C$ dalam pakan untuk meningkatkan kelangsungan hidup benih ikan lele dumbo. Metode yang digunakan Partisipasi Aktif, meliputi pembekalan teori, praktek lapang, demonstrasi plot dan pendampingan. Hasil realisasi kegiatan pengabdian kepada masyarakat ini dapat dibedakan dalam tiga tahap yaitu: persiapan, pelaksanaan dan evaluasi hasil. Persiapan dilakukan setelah melakukan survei. Pelaksanaan program dilakukan secara fisik dan non fisik. Kegiatan fisik dievaluasi berdasarkan pemantauan sikap dan aktivitas peserta selama mengikuti ceramah serta praktikum, sedangkan non fisik dievaluasi berdasarkan pemahaman peserta terhadap materi yang diberikan selama berlangsungnya ceramah dan diskusi. Evaluasi hasil program dengan menghitung pertumbuhan dan kelangsungan hidup benih ikan lele dumbo yang diberi suplemen vitamin C selama 2 bulan. Hasil dari kegiatan pengabdian adalah pemberian suplemen vitamin $C$ dapat meningkatkan berat dan kelangsungan hidup benih ikan lele dumbo. Transfer teknologi dapat dilaksanakan oleh masyarakat terutama kelompok Karang Taruna Mardi Utomo di Desa Candiwulan, Kecamatan Mandiraja, Kabupaten Banjarnegara.
\end{abstract}

Kata kunci: lele dumbo, pertumbuhan, vitamin C, Desa Candiwulan

\begin{abstract}
Candiwulan is the villages in Banjarnegara Regency which has potential of fisheries which is supported by sufficient water available even in the dry season. One type of fish is African
\end{abstract}


catfish. Constraints are often encountered in African catfish farming is the nursery stage, which seed maintenance after the supply of egg yolks runs out. Seeds are critical stages so that their survival is low. Need to do with an increase in immunity with vitamin C supplements in feed by increasing the body's immunity. The purpose is to educate the people of Candiwulan village to become aware of the management of vitamin $C$ supplementation in feed to improve the survival of African catfish seeds. The method used includes four methods: theoretical debriefing, field practice, plot demonstration and mentoring. The results of the realization of community service activities can be divided into three stages: preparation, implementation and evaluation. Preparation is done after conducting a survey. Program implementation is carried out physically and non-physically. Physical activities are evaluated based on monitoring participants 'attitudes and activities during the lecture and practicum, while non-physical is evaluated based on participants' understanding of the material provided during the lecture and discussion. Evaluation by calculating the growth and survival of African catfish seeds that were given vitamin C supplements for 2 months. Giving vitamin $\mathrm{C}$ supplements can improve the survival and growth of African catfish seeds. Technology transfer can be carried out by the community, especially the Mardi Utomo Organization in Candiwulan Village.

Keywords: African catfish, growth, vitamin C, Candiwulan village

\section{PENDAHULUAN}

Desa Candiwulan termasuk dalam kecamatan Mandiraja yang termasuk wilayah kerja kabupaten Banjarnegara Jawa Tengah. Desa Candiwulan memiliki topografi dengan daerah datar, dengan luas wilayah desa 111,950 Ha. Berdasarkan Monografi Desa (2010) wilayahnya sebagian berupa lahan sawah dengan luas 63,470 Ha, lahan bukan sawah 45,557 Ha dan lahan kolam budidaya sebesar 2,5 Ha. Penduduk desa Candiwulan terdiri dari $716 \mathrm{KK}$ dengan jumlah penduduk laki-laki 1147 dan perempuan 1121, kepadatannya 22 jiwa/Km. Penduduk desa Candiwulan mempunyai mata pencaharian yang beragam yaitu sebagai petani, peternak ikan, peternak unggas, pedagang, buruh dan sebagian kecil pegawai. Sebagian penduduk desa Candiwulan yaitu sebanyak $50 \mathrm{KK}$ melakukan budidaya perikanan darat karena wilayah ini cukup tersedia air Kurangnya pengetahuan tentang perikanan didesa Candiwulan mengakibatkan produksi kolam budidaya hanya 1,2 ton per tahun sehingga belum dapat meningkatkan pendapatan dan kesejahteraan penduduk.

Berdasarkan hasil observasi di lapangan diketahui bahwa selain mata pencaharian pokoknya, masyarakat desa Candiwulan sebagian besar mempunyai kegiatan sampingan sebagai peternak ikan untuk menambah penghasilan. Kegiatan ini banyak dilakukan karena kualitas air dengan kedalaman air 20 meter dan lingkungannya sangat mendukung. Jenis-jenis ikan air tawar yang dipelihara sebagian besar jenis ikan lele. Kendala yang sering dihadapai dalam budidaya ikan lele adalah pada tahapan pendederan yaitu tahapan awal pemeliharaan benih setelah persediaan kuning telur habis. Tahapan benih dalam budidaya ikan lele merupakan tahapan kritis sehingga kelangsungan hidupnya rendah. Kelangsungan hidup benih ikan lele rentan terhadap penyakit yang disebabkan oleh bakteri sehingga perlu penanganan yang lebih intensif. Hasil penelitian Yuniarsi et al, 2013 bahwa pemberian ragi dan vitamin $\mathrm{C}$ dapat meningkatkan kelangsungan hidup benih ikan mas. Hal ini dapat diterapkan pada ikan lele yang memiliki nilai kelangsungan hidup yaitu sebesar 51,6\% lebih rendah diantara ikan nila, nilem dan mas (Setyaningrum \& Wibowo, 2016).

Kendala yang dihadapi dalam kegiatan budidaya adalah masalah penyakit. Penyebab timbulnya penyakit pada ikan umumnya terjadi karena adanya interaksi antara ikan, patogen dan lingkungan (Anderson, 1974). Pada kondisi lingkungan yang normal, keberadaan patogen 
tidak menimbulkan gejala penyakit, namun pada budidaya dengan kondisi lingkungan yang terbatas, kepadatan tinggi dan pengelolaan kualitas air yang kurang tepat menyebabkan keseimbangan lingkungan terganggu, sehingga ikan menjadi stres dan patogen dapat berkembang menjadi penyakit yang dapat mematikan. Pencegahan perluasan penyakit dapat dilakukan secara dini, antara lain dengan peningkatan kekebalan tubuh dengan penambahan vitamin $\mathrm{C}$ pada pakan. Vitamin $\mathrm{C}$ berguna untuk mencegah pengaruh negatif dari gangguan lingkungan atau stres, mempercepat penyembuhan luka dan meningkatkan pertahanan alami melawan infeksi bakteri. Pemberian vitamin $\mathrm{C}$ dosis tinggi bermanfaat bagi ikan yang terserang penyakit atau stres. Hasil penelitian Yuniarsi et al., (2013) bahwa kelangsungan hidup terbaik pada pendederan benih ikan mas dengan pemberian vitamin $\mathrm{C}$ sebanyak 750 $\mathrm{mg} / \mathrm{kg}$ pakan.

Untuk meningkatkan pengetahuan tentang budidaya ikan secara intensif dan cara meningkatkan kelangsungan hidup benih ikan lele dumbo perlu alih teknologi tentang manajemen pemberian vitamin $\mathrm{C}$ dalam pakan. Adanya keterbatasan dalam mengatasi permasalahan khususnya dalam budidaya ikan oleh peternak ikan, baik yang menyangkut sarana dan prasarananya serta pengetahuan yang dimiliki oleh sumber daya manusianya, menyebabkan produksi ikan air tawar yang diperoleh belum optimal.

Tujuan melakukan kegiatan pengabdian kepada masyarakat adalah untuk mendidik masyarakat desa Candiwulan Kabupaten Banjarnegara menjadi paham tentang manajemen pemberian suplemen vitamin $\mathrm{C}$ dalam pakan untuk meningkatkan kelangsungan hidup benih ikan lele dumbo sehingga dapat meningkatkan produksi.

\section{METODE PELAKSANAAN}

Metode yang digunakan partisipasi aktif meliputi empat cara: pembekalan teori, praktek lapang, demonstrasi plot dan pendampingan.

Pembekalan teori dimaksudkan mendidik peserta dengan memberikan pengetahuan tentang manfaat vitamin $\mathrm{C}$ dalam pakan untuk meningkatkan produksi benih ikan lele dumbo. Praktek lapang dimaksudkan untuk menerapkan hasil pengetahuan secara teoritis dan pengenalan secara nyata hasil teori yang telah disampaikan, sehingga proses alih teknologi yang diharapkan dapat mencapai sasaran. Demonstrasi Plot dimaksudkan untuk mempraktekkan semua pengetahuan baik teori maupun praktek dalam bentuk nyata. Pendampingan dilakukan agar kegiatan ini dapat berjalan secara berkesinambungan dan dilakukan pendampingan secara berkala oleh tim pengabdi dari Fakultas Biologi Unsoed, sehingga peternak ikan yang sudah melakukam metode ini akan lebih berhasil dan percaya diri untuk melakukan kegiatan budidaya ikan terutama tahapan pendederan ikan lele dumbo.

\section{HASIL DAN PEMBAHASAN}

\subsection{Realisasi Pelaksanaan Program}

Kegiatan pengabdian kepada masyarakat yang merupakan sarana alih teknologi ini telah dilaksanakan dengan melibatkan khalayak sasaran di desa Candiwulan kecamatan Mandiraja Kabupaten Banjarnegara. Realisasi pelaksanaan program pengabdian kepada masyarakat ini juga mendapat dukungan penuh dari segenap aparat desa Candiwulan dan Fakultas Biologi Unsoed. Secara garis besar realisasi kegiatan pengabdian kepada masyarakat ini dapat dibedakan dalam tiga tahap yaitu: persiapan, pelaksanaan dan evaluasi hasil.

Langkah awal yang ditempuh tim penyuluh untuk merealisasikan program antara lain adalah menyusun jadwal kegiatan, berkoordinasi dengan aparat desa serta mengurus ijin pelaksanaan dan menyusun makalah penyuluhan. Disamping itu juga mempersiapkan alat dan bahan yang dibutuhkan untuk mendukung kegiatan praktikum di lapang. 
Untuk mempermudah dan memperlancar program kegiatan maka dilakukan penyuluhan dengan cara ceramah dan diskusi sebanyak dua kali tatap muka serta praktek pencampuran vitamin $\mathrm{C}$ ke dalam pellet dilakukan sekali. Praktek lapangan dilaksanakan pada sore hari setelah dilakukan ceramah sehingga peserta masih teringat dengan teori yang sudah diberikan. Ceramah dan praktek dilakukan di balai desa Candiwulan, sedangkan pemeliharaan benih ikan lele dilakukan pada salah satu kolam warga desa Candiwulan. Ceramah dilakukan pada siang hari sekitar pukul 10.00 WIB yang diikuti oleh 21 peserta yang sebagian besar merupakan pembudidaya ikan dan karang taruna desa Candiwulan.

\subsection{Evaluasi Realisasi Pelaksanaan Program}

Ceramah dilaksanakan di balai desa Candiwulan dalam rangka merealisasikan pelaksanaan program pengabdian kepada masyarakat. Balai desa Candiwulan memiliki tempat yang luas dan perlengkapan untuk melakukan ceramah seperti perlengkapan listrik dan penempatan layar yang lebih memadai, sehingga dapat menggunakan LCD dan Laptop. Dengan penayangan gambar dan vidio tentang teknik pembuatan pakan buatan peserta menjadi lebih tertarik dan antusias dalam mengikuti kegiatan ceramah. Hal ini tercermin dengan banyaknya pertanyaan yang diajukan oleh peserta, bahkan ada beberapa pertanyaan di luar topik, sehingga masih banyak permasalahan yang dihadapi oleh pembudidaya ikan selain teknik pembuatan pakan buatan.

Peserta penyuluhan yang diundang dipilih dengan pertimbangan telah memiliki pengetahuan dasar tentang budidaya tetapi ingin mempelajari bagaimana cara membuat pakan buatan untuk ikan. Peserta yang terpilih mewakili dari aparat desa, pembudaya ikan, karangtaruna, dan pemerhati masalah perikanan. Tim penyuluh mengundang 40 orang peserta, namun pada kenyataannya yang hadir hanya 21 orang (Gambar 1). Peserta yang tidak hadir sebagian besar dari unsur pengurus desa karena sibuk dengan kegiatan masing-masing. Meskipun demikian peserta yang dapat hadir sudah dapat memenuhi kriteria yang diharapkan, karena sebagian besar petani ikan yang hadir adalah pembudidaya dan pemerhati masalah perikanan yang senantiasa ingin meningkatkan wawasannya.

Hasil pelaksanaan program pengabdian kepada masyarakat ini dapat dilihat dari segi fisik serta non fisik. Hasil fisik dievaluasi berdasarkan pemantauan sikap dan aktivitas peserta selama mengikuti ceramah serta praktikum cara mencampur pellet dengan vitamin $\mathrm{C}$ pada dosis yang sudah ditentukan dan cara pemberiannya pada ikan. Adapun hasil non fisik dievaluasi berdasarkan pemahaman peserta terhadap materi yang diberikan selama berlangsungnya ceramah dan diskusi.

Penyelenggaraan penyuluhan yang dilakukan dalam bentuk ceramah dan praktikum ternyata mampu meningkatkan pengetahuan peserta. Hal ini dapat dilihat dari adanya peningkatan pemahaman peserta terhadap pengetahuan tentang teknik budidaya ikan dengan manajemen pemberian serta manfaat pemberian vitamin $\mathrm{C}$ dalam pakan. Dengan demikian dapat dikatakan bahwa materi penyuluhan dapat diterima dan dipahami oleh peserta penyuluhan.

Evaluasi dampak terhadap hasil fisik yang telah dicapai dalam kegiatan penyuluhan ini dilakukan sejak peserta mendapatkan ceramah hingga berakhirnya kegiatan praktikum. Hasil evaluasi menunjukkan bahwa 10 0rang kader mampu melakukan kegiatan teknik mencampur pakan dengan vitamin C. Kemudian dilakukan pendampingan oleh tim penyuluh dari Fakultas Biologi sampai dengan 2 bulan agar kegiatan ini tidak berhenti dan terus berlangsung.

Hasil fisik yang telah dicapai secara kuantitatif sudah bagus dan pencapaian hasil ini sangat menggembirakan karena mereka sudah mampu melakukan budidaya ikan lele dumbo dengan manajemen pemberian vitamin $\mathrm{C}$. Hal ini mengindikasikan bahwa sosialisasi tentang pemanfaatan vitamin $\mathrm{C}$ dalam pakan untuk meningkatkan kelangsungan hidup benih ikan lele 
dumbo mendapat respon positif dari peserta. Hasil ini menginformasikan bahwa telah terjadi peningkatan ketrampilan dan pengetahuan tentang teknik budidaya ikan lele dumbo .

Faktor pendorong yang menunjang keberhasilan pelaksanaan program pengabdian kepada masyarakat ini antara lain adalah adanya kerjasama yang baik antara penyelenggara dengan segenap peserta dengan aparat desa Candiwulan. Selain itu dengan adanya dukungan sarana dan prasarana dari laboratorium Biologi akuatik Fakultas Biologi Unsoed sangat membantu terlaksananya program ini. Faktor penghambat dalam menerapkan program ini adalah latar belakang dan tingkat pendidikan peserta yang beragam sehingga kurang paham dengan beberapa istilah yang digunakan dalam ceramah.

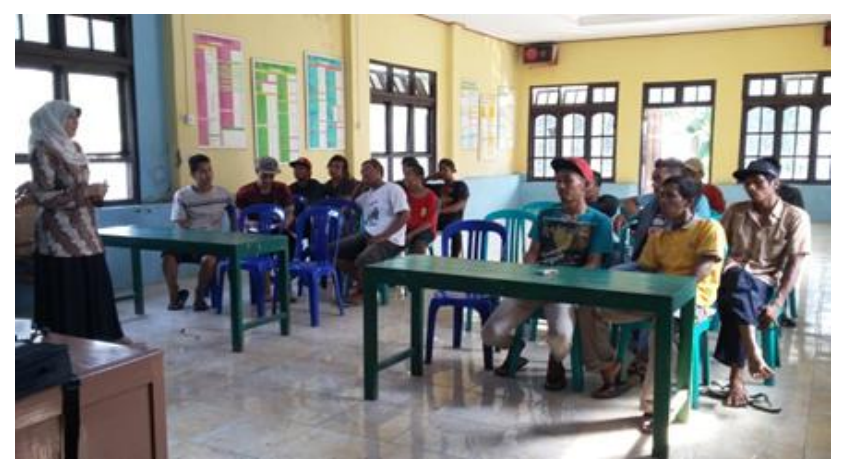

Gambar 1. Pelaksanan penyuluhan

\subsection{Evaluasi Hasil Pemberian Suplemen Vitamin C dalam Pakan Untuk Meningkatkan Produksi Ikan Lele}

Pemeliharaan benih ikan lele dumbo dilaksanakan selama 2 bulan di salah satu kolam warga yang tergabung dalam kelompok Karang Taruna Mardi Utomo. Perlakuan yang dicobakan pada 2 kolam pemeliharaan ukuran $2 \times 3 \mathrm{~m}^{2}$ yaitu pemberian pellet dengan suplemen vitamin $C$ dan tanpa pemberian suplemen vitamin $C$. Kepadatan benih tiap kolam sebanyak 2000 ekor. Setiap 2 minggu sekali di ambil sampel untuk diukur berat dan panjang, sedangkan untuk kelangsungan hidup di amati ikan yang mati setiap hari. Setiap 2 minggu sekali ada peningkatan berat dan panjang ikan kemudian dilakukan grading dengan memisahkan ikan yang ukuran seragam, untuk menghindari terjadinya kanibalisme pada masing-masing perlakuan.

Berdasarkan hasil evaluasi kepada peserta penyuluhan di peroleh bahwa peserta belum mengetahui tentang manfaat vitamin $\mathrm{C}$ bila di campur dalam pakan sehingga perlu dilakukan uji coba untuk mengetahui peningkatan berat ikan. Berdasarkan hasil monitoring dan evaluasi setiap 2 minggu sekali diperoleh peningkatan berat, berat akhir dan kelangsungan hidup ikan lele dumbo selama 2 bulan (Tabel 1).

Tabel 1. Peningkatan berat (g) dan Kelangungan hidup (\%) Ikan Lele Dumbo

\begin{tabular}{|c|c|c|}
\hline Pengambilan Sampel & Pellet & Pellet + vitamin $C$ \\
\hline Awal & 0.76 & 0,76 \\
\hline I & 0,8775 & 0,884 \\
\hline II & 1,0345 & 1,695 \\
\hline III & 5,71 & 6,31 \\
\hline IV & 13,59 & 15,49 \\
\hline Peningkatan berat & 12,83 & 14,73 \\
\hline Produksi & 17,96 & 26,51 \\
\hline Kelangsungan hidup (\%) & 70 & 90 \\
\hline
\end{tabular}


Peningkatan berat ikan tanpa suplemen vitamin $\mathrm{C}$ berat rata-rata $12,83 \mathrm{~g}$ dan berat akhir sebesar 13,59 g. Sedangkan peningkatan berat ikan dengan suplemen vitamin C menghasilkan peningkatan berat rata-rata sebesar $14,73 \mathrm{~g}$ dan berat akhir rata-rata sebesar $15,49 \mathrm{~g}$.

Pemberian suplemen vitamin $\mathrm{C}$ menghasilkan pertumbuhan terbaik yang tercermin dengan peningkatan berat dibandingkan dengan tanpa pemberian suplemen vitamin $\mathrm{C}$. Vitamin $\mathrm{C}$ berperan dalam meningkatkan daya tahan tubuh benih ikan lele dumbo yang pada tahap pendederan ini merupakan tahapan yang kritis. Johnny at al., (2007) menjelaskan bahwa vitamin $\mathrm{C}$ adalah nutrien yang dibutuhkan untuk proses fisiologis hewan, termasuk ikan dan merupakan nutrien esensial. Vitamin $\mathrm{C}$ merupakan salah satu bahan yang sering digunakan dalam pencegahan penyakit ikan, vitamin $\mathrm{C}$ dalam tubuh ikan berperan mengurangi stress dan mempercepat proses penyembuhan luka (Suprayudi et al., 2006). Vitamin C memiliki banyak peranan, salah satunya sebagai imunostimulan. Imunostimulan merupakan sekelompok senyawa biologi dan sintetis yang dapat meningkatkan tanggap kebal spesifik dan non-spesifik (Roza et al., 2005).

Berdasarkan hasil uji coba pemeliharaan benih ikan lele dumbo di kolam (Gambar 2) bahwa peningkatan berat ikan dengan suplemen vitamin $\mathrm{C}$ dapat meningkatkan kelangsungan hidup $(90 \%)$ dan tercermin dengan peningkatan produksi $(26,51 \%)$ bila dibandingkan dengan pemberian pellet tanpa suplemen vitamin C. Hal ini dapat meningkatkan pendapatan pembudidaya ikan.

Pemeliharaan benih ikan lele dumbo pada tahapan pendederan merupakan tahapan yang kritis karena penyesuaian dengan pakan tambahan dan kualitas air tempat pemeliharaan. Pada tahapan ini bila tidak diberi perlakuan dengan vitamin $\mathrm{C}$ mengakibatkan mortalitas yang tinggi, terutama pada saat musim kemarau mudah terserang penyakit sehingga ikan akan mati. Dengan pemberian vitamin $\mathrm{C}$ yang berfungsi untuk meningkatkan daya imunitas atau kekebalan tubuh ikan dan dapat meningkatkan nafsu makan ikan sehingga kelangsungan hidup benih ikan lele dumbo dapat terus terjaga.

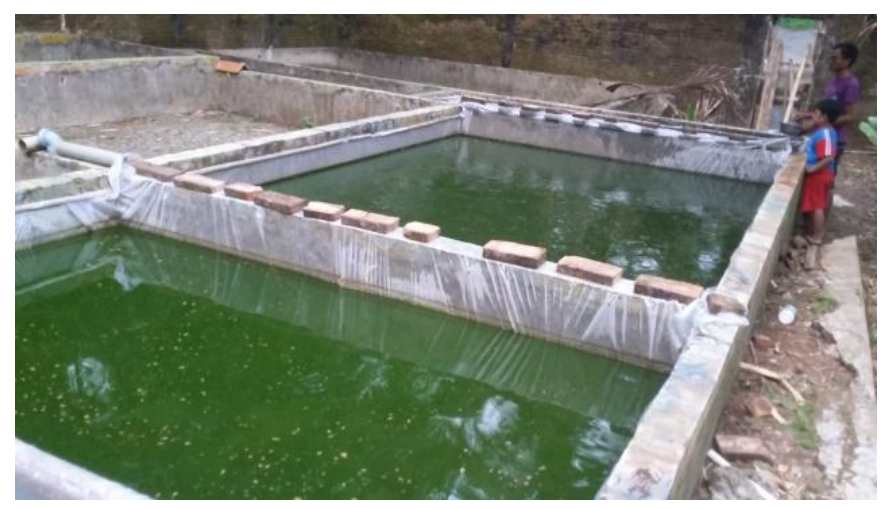

Gambar 2. Kolam pemeliharaan ikan lele dumbo.

Peserta penyuluhan telah memahami manfaat penggunaan vitamin $\mathrm{C}$ dalam pakan untuk meningkatkan kelangsungan hidup benih ikan lele dumbo. Demplot diberikan dalam melakukan budidaya ikan lele dumbo tahapan pendederan, sebagai program percontohan terutama untuk karang taruna dan pembudidaya ikan. Hasil dari budidaya pendederan ikan lele dumbo sebagai modal awal untuk melakukan budidaya bagi generasi muda desa Candiwulan yang sebagian tidak memiliki kegiatan yang dapat menghasilkan pendapatan. Modal awal ini dapat dilanjutkan untuk melakukan budidaya yang lebih baik dan dapat meningkatkan kegiatan pemeliharaan benih ikan lele dumbo dan juga jenis ikan lain.

Pihak Universitas berharap kepada masyarakat desa candiwulan untuk secara konsisten melakukan kegiatan di bidang perikanan dengan memanfaatkan sumberdaya alam yang 
mendukung yaitu melimpahnya ketersediaan air meskipun dalam musim kemarau. Air sebagai faktor utama keberlangsungan budidaya perikanan di Desa Candiwulan.

\section{KESIMPULAN}

Berdasarkan hasil monitoring dan evaluasi selama melakukan kegiatan pengabdian kepada masyarakat di Desa Candiwulan Kecamatan Mandiraja, Kabupaten Banjarnegara diperoleh kesimpulan sebagai berikut:

1. Pemberian suplemen vitamin $\mathrm{C}$ dapat meningkatkan kelangsungan hidup dan pertumbuhan benih ikan lele dumbo di desa Candiwulan Kecamatan Mandiraja Kabupaten Banjarnegara.

2. Transfer teknologi dapat dilaksanakan oleh masyarakat terutama kelompok Karang Taruna Mardi Utomo di Desa Candiwulan, Kecamatan Mandiraja, Kabupaten Banjarnegara.

\section{UCAPAN TERIMA KASIH}

Diucapkan terima kasih kepada Badan Layanan Umum (BLU) Unsoed yang telah mendanai kegiatan Pengabdian Kepada Masyarakat (PKM) ini.

\section{DAFTAR PUSTAKA}

Anderson,.D.P. 1974. Fish Immunology. TFH Publication Ltd. Hongkong.

Anonim. 2010. Monografi Deca Candiwulan Kecamatan Mandiraja Kabupaten Banjarnegara.

Johnny, F., K. Mahardika, I.N.A. Giri dan D. Roza. 2007. Penambahan Vitamin C dalam Pakan untuk meningkatkan Imunitas Benih Ikan Kerapu Macan, Epinephelus fuscoguttatus terhadap Infeksi Viral Nervous Necrosis. Jurnal Akuakultur Indonesia, 6(1) : 43-53.

Nuranto. 1991. Pengaruh Vitamin C Terhadap Pertumbuhan Ikan Lele (Clarias batrachus). Tesis. PPs. Institut Pertanian Bogor. 73hal

Roza, D., F. Johnny, dan Zafran. 2010. Pengembangan Vaksin Bakteri untuk meningkatkan Imunitas Ikan Kerapu Macan (Epinephelus fuscoguttatus) terhadap Penyakit Infeksi. Prosiding Forum Inovasi Teknologi Akuakultur.

Suprayudi, M. A., L. Indriastuti,, dan M. Setiawati. 2006. Pengaruh Penambahan BahanBahan Imunostimulan Dalam Formulasi Pakan Buatan TerhadapRespon Imunitas dan Pertumbuhan Ikan Kerapu Bebek, Cromilepte saltivelis. Jurnal Akuakultur Indonesia, 5(1) : 77-86.

Setyaningrum, N dan E.S. Wibowo. 2016. Potensi Reproduksi Ikan Air Tawar Sebagai Baby Fish. Jurnal Biosfera, 33(2):85-91.

Yuniarsi,T,., L. Santoso dan E. Harpeni. 2013. Pengaruh Penambahan Ragi (YEAST) Dan Vitamin C Pada Pakan Buatan Sebagai Imunostimulan Terhadap Respon Imun Non Spesifik Ikan Mas (Cyprinus carpio) Yang Diuji Tantang Aeromonas salmonicida. Skripsi Fakultas Perikanan Unila. Lampung. 